DOI: $10.15290 /$ bsl.2017.10.09

\author{
Anna Tomczak \\ Wydział Filologiczny \\ Uniwersytet w Białymstoku \\ e-mail: atomczak@uwb.edu.pl
}

\title{
Ironia modernistyczna i nowy rodzaj biografii: Ludzie epoki Wiktorii Lyttona Stracheya
}

Jak zauważa Dorota Korwin-Piotrowska, ironia „[j]est zjawiskiem wymykającym się łatwym definicjom"1. Stanowi zarówno kategorię metafizyczną, będąc rodzajem postawy intelektualnej, jak i typ dyskursu. Jako kategoria literacka może stanowić figurę retoryczną i środek stylistyczny, może posługiwać się zabiegiem przywołania i tropem semantyczno-pragmatycznym². Istotą ironii werbalnej jest sprzeczność logiczna i niedopasowanie, rozbieżność między dosłownym a intencjonalnym znaczeniem wypowiedzi, polegająca na tym, że to, co wypowiedziane ma znaczenie przeciwne lub odmienne od zamierzonego ${ }^{3}$, a zatem „podstawowym wyznacznikiem wypowiedzi ironicznej jest podwójność w strukturze znaczeniowej" ${ }^{4}$. Ironia postrzegana jest też jako dyspozycja psychiczna ${ }^{5}$, jako sytuacja antropologiczna i postawa in-

1 D. Korwin-Piotrowska, Poetyka: przewodnik po świecie tekstów, Kraków 2011, s. 315.

2 Zob. D. Sperber i D. Wilson, Ironia a rozróżnienie między użyciem a przywołaniem, przeł. M. B. Fedewicz, w: Ironia, red. M. Głowiński, Gdańsk 2002, s. 75-108; C. Kerbrat-Orecchiani, Ironia jako trop, przeł. M. Dramińska-Joczowa, w: tamże, s. 109-143.

3 Zob. S. Rodriguez Rosique, The power of inversion. Irony, from utterance to discourse, w: Irony and Humour. From Pragmatics to Discourse, ed. L. Ruiz Gurillo i M. Belén Alvaro Ortega, Amsterdam/Philadelphia 2013, s. 17-38.

4 P. Łaguna, Ironia jako postawa i jako wyraz, Kraków-Wrocław 1984, s. 69.

5 Zob. B. Allemann, O ironii jako o kategorii literackiej, przeł. M. Dramińska-Joczowa, w: Ironia, red. M. Głowiński, Gdańsk 2002, s. 17-41. 
telektu ${ }^{6}$, sposób porządkowania rzeczywistości ${ }^{7}$, a także jako akt komunikacyjny, który „pozwala ustalić [...] stosunki z odbiorcą" ${ }^{8}$, i któremu towarzyszy zarówno poczucie wyższości ironisty, jak też oczekiwanie „solidarności w procesie obopólnego porozumienia" ${ }^{9}$.

Linda Hutcheon podkreśla, że choć z jednej strony ironia ma charakter "transideologiczny" 10, gdyż może służyć najróżniejszym poglądom i stanowiskom, to z drugiej - jej odczytanie zawsze wymaga znajomości kontekstu, np. wiedzy na temat rzeczywistych przekonań autora i światopoglądu epoki. Dostrzeżenie ironii przebiega w określonych warunkach i związane jest z pewnym rodzajem współpracy między ironistą a interpretatorem, wymaga zatem istnienia „wspólnoty dyskursywnej” ${ }^{11}$, będącej pochodną podobnego bagażu edukacyjno-społecznego nadawcy i odbiorcy uczestniczących w akcie komunikacji. Wymiar semantyczny ironii jako narzędzia walki nie może być oddzielony od jej tła historyczno-kulturowego. Celnie wymierzone ostrze wypowiedzi ironicznej wywołuje z reguły reakcję emocjonalną, której natężenie jest swoiste i kulturowo zależne, wynikające zarówno ze specyfiki istniejącej wspólnoty, jak i jednostkowo zmiennej siły rażenia dyskursu. Skoro ironista zakłada, że odbiorca „posiada już niezbędną wiedzę na dany temat" ${ }^{12}$, która umożliwia odpowiednie odwołania i aluzje, posługiwanie się ironią może zmierzać do zacieśnienia więzi ze wspólnotą.

Eminent Victorians (Ludzie epoki Wiktorii) Lyttona Stracheya jest nie tylko znamiennym przykładem wykorzystania ironii w akcie komunikacyjnym, lecz też propozycją posłużenia się ironią werbalną $w$ akcie tworzenia, $w$ tym przypadku akcie tworzenia nowego rodzaju biografii literackiej. Dzieło Stracheya ilustruje tezę, że "nie ma jednej ironii" ${ }^{13}$, a ironia jako postawa i jako wyraz świadomości przejawia się wprawdzie w wykładnikach tekstowych, lecz jej charakter jest zmienny, stale ewoluujący, zależny od odbiorcy i funkcji wypowiedzi. Utwór Stracheya można interpretować jako przejaw modernistycznej postawy autora kwestionującego istnienie jedynej prawdy, kontestu-

6 Zob. Z. Mitosek, Co z tq ironiq?, Gdańsk 2013, s. 12, 355.

7 Zob. A. Walczuk, Irony as a Mode of Perception and Principle of Ordering Reality in the Novels of Muriel Spark, Kraków 2005, s. 11.

8 M. Głowiński, Ironia jako akt komunikacyjny, w: Ironia, s. 6.

9 P. Łaguna, Ironia jako postawa i jako wyraz, s. 37.

10 L. Hutcheon, Irony's Edge: The Theory and Politics of Irony, London and New York 1995, s. 9, 43. (Wszystkie tłumaczenia z tekstów anglojęzycznych, których autorstwo nie zostało wskazane, pochodzą od autorki).

11 Tamże, s. 85 i dalej.

12 D. S. Muecke, Ironia: podstawowe klasyfikacje, przeł. G. Cendrowska, w: Ironia, s. 69.

13 Z. Mitosek, Co z tą ironia?, s. 12. 
jącego autorytety i pochwałę wielkości, co znajduje potwierdzenie w zabiegach artystycznych tekstu adresowanego do odbiorcy ukształtowanego przez klimat intelektualny czasów powiktoriańskich, zwłaszcza dwóch pierwszych dekad dwudziestego wieku.

Ludzie epoki Wiktorii to zbiór czterech biografii znanych postaci życia publicznego dziewiętnastowiecznej Anglii: kardynała Manninga, Florence Nightingale, Thomasa Arnolda i Generała Charlesa Gordona, tekstów spisanych w trudnych i tragicznych latach pierwszej wojny światowej (1916-1918) i opublikowanych w maju 1918 roku w atmosferze skandalu. Zamiarem autora intelektualisty i krytyka literackiego związanego z grupą Bloomsbury - było zaproponowanie nowego podejścia do biografistyki, zerwanie z powszechnie obowiązującą formułą, według której przeniesiona na papier historia jednostkowego życia przybierała postać hagiograficzną, a wstydliwe lub niewygodne fakty pomijane były milczeniem. W krótkiej przedmowie Strachey stwierdza:

Sztuka pisania życiorysu przeżywa zdaje się w Anglii złe czasy [...]. Najbardziej delikatna i najbardziej ludzka ze wszystkich gałęzi sztuki pisarskiej została u nas zdegradowana do roli rzemiosła, którym zajmują się wyrobnicy literatury [...]. Owe dwa grube tomy, którymi mamy zwyczaj oddawać hołd pamięci zmarłych - któż ich nie zna, z ich nieprzetrawioną masą materiału, byle jakim stylem, $\mathrm{z}$ ich nutą ckliwie panegiryczną i żałosnym brakiem wyboru, obiektywizmu, konstrukcji! Zżyliśmy się z nimi, jak zżyliśmy się z widokiem konduktu pogrzebowego; są tak samo, jak ów kondukt, uroczystym obrządkiem żałobnym barbarzyńców ${ }^{14}$.

Rzeczywiście, jak podkreślają historycy gatunku, w epoce wiktoriańskiej królowała „pseudo-biografia” 15 i przeważała opinia, jakoby opisanie cudzego żywota służyło nieodmiennie celom dydaktycznym. Powinno zatem dotyczyć wyłącznie ludzi wybitnych i znamienitych, których historie mogły stać się przykładem nienagannej postawy moralnej, żarliwego patriotyzmu, służby publicznej oraz urzeczywistnionych wartości chrześcijańskich, co prowadziło w rezultacie do przedstawiania "życia wypranego" ${ }^{16}$. Wszystkie cztery postacie wybrane przez Stracheya w powszechnym mniemaniu uchodziły za osoby zasłużone i wyjątkowe. Wszystkie utożsamiały jednocześnie wiktorianizm, nie tylko $\mathrm{w}$ oczach autora, lecz przede wszystkim $\mathrm{w}$ rozumieniu opinii publicznej. I tak, Kardynał Manning, czyli Henry Edward Manning (1808-1892), konwertyta, który przeszedł na katolicyzm w 1851 roku, to przykład człowieka Kościoła, oddanego sługi Boga pochowanego w dowód uzna-

\footnotetext{
${ }^{14}$ L. Strachey, Ludzie epoki Wiktorii. Florence Nightingale. Generał Gordon, przeł. A. Pański, Warszawa 1938, s. 7-8. Kolejne cytaty są lokalizowane w tekście głównym.

15 N. Hamilton, Biography. A Brief History, Cambridge, Ma. and London, 2007, s. 100.

16 Tamże, s. 111.
} 
nia $\mathrm{w}$ katedrze westminsterskiej $\mathrm{w}$ Londynie, przykład męża stanu, który całym swym życiem starał się propagować sprawiedliwość społeczną i poniósł niemałe zasługi w tworzeniu klasztorów i szkół katolickich. Florence Nightingale (1820-1910) to kobieta czynu, prekursorka nowoczesnego pielęgniarstwa, która bezprzykładnie poświęciła swe życie potrzebującym, niosąc pomoc rannym i chorym w czasach wojny krymskiej. Doktor Thomas Arnold (1795-1842) - wieloletni dyrektor prestiżowej męskiej szkoły w Rugby - to zasłużony edukator i autorytet wychowawczy, upamiętniony pośmiertnie w popularnej powieści Thomasa Hughesa Tom Brown's Schooldays (1857), zaś Generał Charles George Gordon (1833-1885) zasłynął jako bohaterski żołnierz i dowódca bezgranicznie oddany idei Imperium. Kiedy po ponad trzystu dniach oporu poległ podczas oblężenia Chartumu przez Mahdystów (lub jakbyśmy dziś mogli rzec "jihadystów" ${ }^{17}$ ) niemalże okrzyknięto go świętym i „,najbardziej dramatycznym męczennikiem imperium” "18, który wierzył w cel moralny zdobyczy kolonialnych i którego postawa, w opinii narodu, uświęcała kolonialne poczynania Anglii jako misję cywilizacyjną.

Proponując nowy rodzaj biografii literackiej i zarazem nowe spojrzenie na życie „wybitnych” przedstawicieli czasów królowej Wiktorii, Strachey pisał:

Badacz przeszłości, który chce odmalować obraz tej szczególnej epoki [epoki wiktoriańskiej], nie może posługiwać się metodą systematycznej, skrupulatnej narracji: jeśli jest człowiekiem rozumnym, zastosuje subtelniejszą strategię. Atakować będzie swój temat $\mathrm{w}$ miejscach nieoczekiwanych; uderzy na skrzydła, albo na tyły; oświetli nagłym i przejmującym światłem reflektora ciemne, niezbadane dotąd zakamarki. Będzie sobie wiosłował po powierzchni tego oceanu materiału, zanurzając weń tu i ówdzie małe wiaderko i wydobywając na światło dzienne jakiś ciekawy okaz głębinowy, aby mu się przyjrzeć dokładnie [s. 5-6].

Jako człowiek rozumny, uczynił to, co zapowiedział: zaatakował. Przypuścił atak frontalny na wartości wiktoriańskie, ośmieszając i wyszydzając zarówno panujące przekonania, jak i swoich bohaterów, obnażając ich hipokryzję i świętoszkowate poczucie wyższości, przekłuwając balon wybujałego ego tzw. „wielkich” tamtych czasów. Dla potomnych książka Stracheya stała się przykładem ikonoklazmu, obrazoburstwa okrutnego, w którym cel uświęca środki, biografii obnażające ${ }^{19}$, zrzucającej okowy dydaktyzmu i natrętnego moralizatorstwa, lecz jednocześnie fałszującej fakty. Rzekome wydobywanie na światło dzienne ciekawych okazów oznaczało często wymyślanie

\footnotetext{
17 J. Paxman, Empire, London 2011, s. 178.

18 Tamże, s. 176.

19 W oryginale: „debunking biography” [zob. R. Skidelsky, Only Connect: Biography and Truth, w: The Troubled Face of Biography, ed. E. Homberger i J. Charmley, New York, 1988, s. 6].
} 
scen z przeszłości, które nigdy nie miały miejsca i dołączanie do tekstu wydumanych monologów wewnętrznych. W styczniu 2017 roku dzieło Stracheya zaliczone zostało na łamach Guardiana do grona stu najważniejszych światowych pozycji literatury non-fiction ${ }^{20}$. Bezsprzecznie, do dziś, stanowi przykład programowego odrzucenia dawnych wzorców i mistrzowskiego wykorzystania ironii.

Przekład nie zawsze jest w stanie zachować wymiar ironiczny tekstu ${ }^{21}$. Zwłaszcza subtelna ironia „narażona jest na zniekształcenie w procesie tłumaczenia" 22. Tak jest także w przypadku książki Stracheya. Tom, który ukazał się w Polsce w 1938 roku w tłumaczeniu Antoniego Pańskiego, nie jest tekstem integralnym. Zawiera dwa z czterech szkiców biograficznych, te opisujące życie Florence Nightingale i Generała Gordona oraz przypis wydawcy informujący, że pozostałe eseje „wydane zostaną oddzielnie” [s. 5]. Różnice między polską i angielską wersją widoczne są już na poziomie paratekstu. Polski tytuł Ludzie epoki Wiktorii pomija istotny epitet „eminent”, który oznacza: „nadzwyczajny, wyjątkowy, wybitny” i używany jest dla podkreślenia znakomitości w danej dziedzinie. W dosłownym tłumaczeniu „eminent Victorians" to „wybitni Wiktorianie" lub „wielcy Wiktorianie”, a przecież celem Stracheya jest właśnie zakwestionowanie tej wielkości. W przypadku anglojęzycznego odbiorcy, ironia tytułu jest odczytana w trakcie lektury tekstu, kiedy znaczenie literalne przymiotnika staje w sprzeczności zarówno z wymową poszczególnych esejów jak i wymową całego dzieła. Polski odbiorca niestety traci tę możliwość. Podobnie jest $\mathrm{z}$ tytułem czwartego (w polskim wydaniu drugiego) szkicu Generat Gordon, który w oryginale brzmi The end of General Gordon, gdzie "the end of ..." może odnosić się zarówno do ostatnich chwil życia bohatera, jak i do niesławnego końca narodowego uwielbienia tej kontrowersyjnej postaci. Decyzje tłumacza oznaczają zatem sprowadzenie tytułów do ich funkcji informacyjnej, pozbawiając ich aspektu ironicznego. Nie dziwi więc, że ironiczny wymiar całego tekstu jest czasem dla polskiego czytelnika nie do uchwycenia. Nie jest moim zamiarem krytykowanie przekładu ani wskazywanie istniejących błędów, które się zdarzają. Przywołam tu jedynie te przypadki, w których ironia zostaje zachowana, aby zilustrować twierdzenie, że w Ludziach epoki Wiktorii nie sposób nie dostrzec ironicznej postawy autora, pomimo wielu uproszczeń, a także, iż ostrze ironii często kierowane jest nie przeciwko samym bohaterom książki, lecz czasom,

\footnotetext{
20 R. McCrum, „Eminent Victorians", „Guardian"16.01.2017.

21 K. Barbe, Irony in Context, Amsterdam/Philadelphia, 1995, s. 147.

22 M. Adamczyk-Garbowska, Polskie tłumaczenia angielskiej literatury dziecięcej. Problemy krytyki przekładu, Wrocław 1988, s. 48.
} 
które ich stworzyły oraz społeczeństwu, które wyniosło ich na piedestał. Należy jednak podkreślić za Allemannem, że „ironia literacka [...] nie może nigdy ograniczać się do ironii poszczególnych zdań. [...] [M]ożna nawet wyobrazić sobie tekst bardzo ironiczny, w którym nie znalazłaby się żadna osobna «uwaga ironiczna»" 23. Utwór Stracheya zawiera liczne stylistyczne wykładniki ironii ${ }^{24}$, choć nie zawsze są one czytelne na poziomie mikrotekstu. Zdecydowanie jednak wyraźnie widoczne są takie zabiegi, jak: wtrącenia odautorskie, pytania retoryczne, obecność antyfrazy, zastosowanie mowy pozornie zależnej, występowanie wykrzykników, metafor pejoratywnych, hiperboli, oksymoronu, litoty, licznych powtórzeń, percepcji unaiwnionej i, ogólnie mówiąc, sprzeczności między tym, co się mówi, a tym, co się daje do zrozumienia. Przy czym, co szczególnie istotne, ironię Stracheya należy zaliczyć do kategorii ironii modernistycznej w rozumieniu Alana Wilde'a.

Amerykański krytyk literacki Alan Wilde opublikował w 1981 roku studium na temat wyobraźni ironicznej zatytułowane Horizons of Assent: Modernism, Postmodernism and the Ironic Imagination [Horyzonty zgody: modernizm, postmodernizm i wyobraźnia ironiczna], w którym zaproponowal, jak to nazwali inni, „historyczną teorię ironii” 25, anonsowaną wcześniej w eseju z 1979 roku Modernism and the Aesthetics of Crisis [Modernizm i estetyka kryzysu]. Paul Bové uważa, że do momentu publikacji Horizons of Assent anglo-amerykańska tradycja krytyczna (w odróżnieniu od tradycji europejskiej, zwłaszcza niemieckiej) traktowała ironię wyłącznie w kategoriach ahistorycznych, jako technikę w ramach poetyki ${ }^{26}$. Dopiero Wilde jako pierwszy postulował podejście historyczne i spekulatywne, oparte na założeniu, że ironia związana jest z priorytetem percepcji i bezpośrednio z niego wynika. Wznowiona w 1987 roku rozprawa Wilde'a nadal stanowi istotny punkt odniesienia dla badaczy literatury $\mathrm{XX}$ wieku ${ }^{27}$. Wyodrębniając trzy kategorie ironii, a zarazem trzy typy

23 B. Allemann, O ironii jako o kategorii literackiej, s. 25.

24 Wykładniki stylistyczne podaję za: Z. Mitosek, Co z ta ironiq̨?, s. 59, 85, 177, 330, 361; B. Allemann, O ironii jako o kategorii literackiej, s. 26; L. Hutcheon, Ironia, satyra, parodia - o ironii w ије̨сіи pragmatycznym, przeł. K. Górska, w: Ironia, s. 189-190; C. Kerbrat-Orecchiani, Ironia jako trop, s. 109-143.

25 P. A. Bové, Modern Irony and the Ironic Imagination, "Contemporary Literature" 1982, 23:2, s. 247.

26 Tamże, s. 245 [w oryginale: „merely concerned with irony as a technique of poetic language"].

27 Zob. np. D. Melbye, Irony in the Twilight Zone: How the Series Critiqued Postwar American Culture, Lanham 2016; A. Walczuk, Irony as a Mode of Perception and Principle of Ordering Reality in the Novels of Muriel Spark; J. A. Dane, The Critical Mythology of Irony, Athens and London 2011; B. May, The Modernist as Pragmatist: E. M. Forster and the Fate of Liberalism, Columbia and London 1997. 
wyobraźni ironicznej zakorzenionej w sposobie odbierania rzeczywistości, Wilde umieszcza je w określonych ramach czasowych. I tak, ironię mediacji (mediate irony) umieszcza w latach poprzedzających modernizm, ironię rozłączenia (disjunctive irony) przypisuje modernizmowi, zaś ironię zawieszenia (suspensive irony) łączy z postmodernizmem ${ }^{28}$. Chociaż, jak zaznacza, wprowadzona typologia nie ma charakteru absolutnego i dotyczy jedynie poszukiwania pewnych znamiennych wyróżników, i chociaż - jak przyznaje - każdy $\mathrm{z}$ trzech wyodrębnionych typów może znaleźć odzwierciedlenie w tekstach różnych epok historycznych, zwraca uwagę na pewne dostrzegalne tendencje i związki. Zauważa, na przykład, że przedmodernistyczna ironia mediacji (mediate irony, premodernist) powiązana jest z satyrą, modernistyczna ironia rozłączenia (disjunctive irony, modernist) z paradoksem, a postmodernistyczna ironia zawieszenia (suspensive irony, postmodernist) $\mathrm{z}$ absurdem. Tak pojęta ironia jako forma postrzegania świata i wizja egzystencji ludzkiej stale ewoluuje i kształtowana jest poprzez uczestnictwo jednostki w wydarzeniach historycznych ${ }^{29}$.

Ironia modernistów jest dla Wilde'a sposobem myślenia i rodzajem wyobraźni, która stara się uchwycić sens z rozsypanych fragmentów. Polega na dwuznaczności i świadomości istnienia wielu alternatywnych rozwiązań i możliwości, świadomości odrzucającej istnienie jedynej prawdy. Jest ironią wynikającą z dostrzegania nieciągłości i rozczłonkowania, co sprzyja postawie dystansu i prowadzi do strategii braku zaangażowania. Modernistyczna ironia to wyraz niemożności znalezienia rozwiązania i przejaw estetyki kryzysu. Jak pisze w artykule Modernism and the Aesthetics of Crisis, modernistyczna ironia absolutna to koncepcja równych sobie i przeciwstawnych możliwości utrzymanych $\mathrm{w}$ stanie całkowitej równowagi, w stanie nierozwiązywalnego i niezniszczalnego paradoksu ${ }^{30}$.

Wielu badaczy ${ }^{31}$ podkreśla związek tak pojętej ironii modernistycznej z jej funkcją krytyki społecznej i z oczekiwaniami wobec odbiorcy. Akcentowany jest także sposób widzenia świata przez pryzmat paradoksu i doświadczenia wewnętrznego, a także artykułowanie chaotycznej rozłączności istnienia i uwypuklenie szczególnej dbałości o artystyczny wymiar wypo-

\footnotetext{
28 A. Wilde, Horizons of Assent: Modernism, Postmodernism, and the Ironic Imagination. Baltimore 1987, s. 9-14.

29 A. Wilde, Modernism and the Aesthetic of Crisis, "Contemporary Literature” 1979, 20:1, s. 25.

30 Tamże, s. 16.

31 D. Melbye, Irony in the Twilight Zone: How the Series Critiqued Postwar American Culture, s. 43; J. A. Dane, The Critical Mythology of Irony, s. 6; T. Miller, Late Modernism: Politics, Fiction, and the Arts between the World Wars, Berkeley-Los Angeles-London 1999, s. 11.
} 
wiedzi ${ }^{32}$. Wprawdzie takie elementy jak dystans ironiczny, ostentacyjne dążenie do perfekcji stylu, czy udramatyzowanie stanów świadomości, najwyraźniej ujawniają się $\mathrm{w}$ powieści modernistycznej, zdaniem Tyrusa Millera dostrzec je można także w innych gatunkach literackich ${ }^{33}$. Utwór Stracheya jest tego najlepszym dowodem. Znajdziemy w nim liczne wyznaczniki tekstowe wymienione przez Wilde'a, np. posługiwanie się parataksą dla zaznaczenia rozłączności i paradoksem $\mathrm{w}$ celu zaakcentowania nielogiczności świata. Zilustrują to poniższe cytaty, zaczerpnięte z polskiego tłumaczenia utworu Stracheya autorstwa Antoniego Pańskiego z publikacji, która ukazała się w 1938 roku, a zatem pochodzące $\mathrm{z}$ dwóch jedynie szkiców biograficznych o Florence Nightingale i Generale Gordonie. Ukazują one przyjętą przez Stracheya taktykę odbrązowienia poprzez ośmieszenie oraz chęć wykpienia tych cech i zasad, które stanowiły trzon wiktorianizmu. Stanowią także przykład, że ironia modernistyczna to dostrzeżenie historycznej zmienności i fenomenologiczne spojrzenie na istotę ludzką zawsze wplątaną $\mathrm{w}$ dzieje historii w konkretnym czasie i miejscu, doświadczającą i aktywnie uczestniczącą w kreacji wydarzeń. Ironista modernistyczny, świadom fragmentaryczności świata, zdecydowanie odrzuca wiarę $w$ istnienie jednej jedynie słusznej drogi postępowania i poddaje surowej krytyce postawę przeciwną. Przejawy takiego stanowiska możemy odnaleźć w biografii Gordona. Kiedy Strachey opisuje stałą obecność Biblii w życiu wiktoriańskiego bohatera, zauważa:

Lektura jego sprowadzała się niemal wyłącznie do czytania Biblii; ale Biblię czytał i wracał do niej ciągle, z niezmordowaną i niewyczerpaną gorliwością. Był przekonany, że w niej znaleźć można całą prawdę; i przekonany był również, że tę prawdę znalazł. Wątpliwości filozofów, badania komentatorów, uśmiechy ludzi światowych, dogmaty kościołów - wszystko to w oczach Pułkownika nie miało żadnego znaczenia. Wszystko zamykało się w treści Biblii i w jego własnej postawie życiowej: jedyne zagadnienie polegało na tym, aby wykryć co nakazuje Biblia - i działać zgodnie z jej wskazówkami. Aby dokonać tego odkrycia, musiał tylko czytać ją jeszcze raz i jeszcze raz od początku - i wobec tego czytał ją przez całe życie [s. 135].

Strachey kpi z naiwnej wiary Gordona i jego braku wątpliwości, z całkowicie niezachwianej pewności Generała, że czyni słusznie, nawet wtedy, gdy postępuje wbrew rozkazom. W literackim portrecie stworzonym przez Stracheya Generał Gordon jawi się jako niesubordynowany dowódca przekonany o swej wiekopomnej roli w utrwalaniu Imperium. Przepełnia go buta, która

32 B. May, The Modernist as Pragmatist: E. M. Forster and the Fate of Liberalism, s. 38; W. Storrm, Irony and the Modern Theatre, Cambridge 2011, s. 202.

33 T. Miller, Late Modernism: Politics, Fiction, and the Arts between the World Wars, s. 11. 
uniemożliwia obiektywną ocenę sytuacji: „wojska Mahdiego... «rozlecą się same». Bowiem zdaniem Gordona, «było rzeczą całkowicie błędną uważać Mahdiego za jakiegoś religijnego przywódcę»; Mahdi załamie się z chwilą, gdy będzie musiał stawić czoło generałowi angielskiemu" [s. 183]. W innym miejscu, Strachey stwierdza:

Generał Gordon był w jak najlepszym nastroju. Nareszcie kwalifikacje jego zostały uznane przez współobywateli; nareszcie powierzono mu zadanie dość wielkie na to, aby mogło zadowolić nawet jego ambicje. Jest już znany - niedługo będzie sławny. Patrząc na znajomy widok pustyni, czuł [...] że oto dla tej właśnie misji Opatrzność ochraniała go w ciągu długich lat trudów i zmartwień. Czemże był wobec niego i cóż mógł mu przeciwstawić Mahdi? [s. 194-195]

\section{I dalej:}

... 18-go lutego odbył się tryumfalny wjazd Gordona do Chartum. Słaby garnizon i przerażeni mieszkańcy miasta witali go jak zbawcę. Nie mieli się już przecież czego obawiać - teraz kiedy wielki pasza angielski jest z nimi [s. 196].

Jako uparty i niezdyscyplinowany wojskowy, gorący zwolennik ekspansji kolonialnej, Gordon nie usłuchał rozkazu o ewakuacji Chartumu i postanowił bronić miasta wbrew decyzjom rządu brytyjskiego, co w rezultacie doprowadziło do sromotnej klęski, upadku garnizonu, śmierci wielu mieszkańców i dwudniowego plądrowania miasta ${ }^{34}$. Był nie tylko przekonany, że lepiej potrafi ocenić sytuację. Uważał odwrót za tchórzostwo, a przecież odwagi mu nie brakło. Jego wizja samego siebie i powierzonej mu wiekopomnej misji stanowi przykład postawy niedopuszczającej wątpliwości, nieogarniającej fragmentaryczności istnienia i negującej jakiekolwiek alternatywy. Strachey stwierdza:

Anglia, z jej problemami i skomplikowaną polityką, stała się dlań pustym dźwiękiem [...] Jest oto "Gordon-Paszą", generał-gubernatorem, władcą Sudanu. Otacza go lud - jego lud - i odpowiedzialny jest tylko wobec niego, i wobec Boga. Czy ma pozwolić, nie próbując nawet walki, aby lud ten dostał się w szpony krwawego szarlatana? Nigdy! Jest tu po to, aby do tego nie dopuścić. Rezydujące za morzami rządy mogły sobie mamrotać o „ewakuacji”; jego myśli zaprzątnięte były zupełnie czym innym [s. 198].

Przytoczone powyżej fragmenty eseju The End of General Gordon zawierają językowe wykładniki ironii modernistycznej wymienione przez Wilde'a.

34 J. Paxman, Empire, s. 182. 
Występują w nich zdania złożone współrzędnie, sygnalizowane przez częste powtórzenie spójnika „i" oraz użycie „również”, „ale”, „bowiem”, zdania niezhierarchizowane semantycznie bądź składniowo, a także następujące po sobie wyliczenia łączące się $\mathrm{w}$ sekwencje, co przypomina technikę montażu, oddając jednocześnie percepcję rozłączności. Podobne zabiegi wykorzystane są w szkicu biograficznym na temat Florence Nightingale, w którym nasycenie językowymi wykładnikami ironii wydaje się szczególnie zauważalne. Pisząc o ambicjach panny Nightingale dotyczących zreformowania wielu dziedzin życia publicznego, Strachey zauważa:

Wzdychała do podboju nowych, wciąż nowych światów. Rozglądała się dokoła: cóż jeszcze pozostawało? Oczywiście! Filozofia! Po świecie czynów, świat myśli. Naprawiwszy stosunki zdrowotne $\mathrm{w}$ armii angielskiej, uczyni teraz to samo dla przekonań religijnych ludzkości. Oddawna [sic!] zauważyła już - z ubolewaniem - rosnące tendencje wolnomyślicielskie wśród pracowników fizycznych. $\mathrm{Z}$ ubolewaniem - ale bez wielkiego zdziwienia: potoczne ujmowanie chrześcijaństwa dawało niestety pole do wielu zarzutów; co więcej - sama doktryna chrześcijańska ma swoje słabe strony. Ona usunie te defekty. Naprawi błędy kościoła; wskaże, co w doktrynie chrześcijańskiej jest niesłuszne; i wytłumaczy robotnikom, na czym polega istota sprawy [s. 97].

Wyliczenia następują także w komentarzu dotyczącym opublikowanych w 1860 roku przez Nightingale Sugestii do przemyślenia dla rzemieślników angielskich poszukujacych prawdy. W opinii biografa, autorka rozwiązuje „na stronicach trzech grubych tomów, trudności - dawniej, rzecz dziwna, nie rozwiązane, a dotyczące zagadnień takich, jak: wiara w Boga, plan stworzenia świata, geneza zła, życie przyszłe, konieczność i wolna wola, prawo i istota moralności” [s. 97-98]. Stwierdziwszy, że: „W szczególności, geneza zła nie miała dla panny Nightingale żadnych tajemnic" [s. 98], Strachey dodaje:

[J]ej koncepcja Boga nie była ortodoksyjna. Zajmowała wobec Niego postawę, jaką mogła zajmować wobec jakiegoś słynnego inżyniera sanitarnego; wydaje się, jak gdyby w niektórych jej rozważaniach Bóstwo było niemal identyczne z należytym systemem wodociągów. Kiedy czyta się te dziwne stronice, ma się wrażenie że panna Nightingale wzięła w swoje obroty nawet Wszechmocnego - który zginie z jej rąk z przepracowania, jeśli nie będzie się miał na baczności [s. 99-100].

Zastosowana technika narracyjna $\mathrm{z}$ wykorzystaniem takich środków stylistycznych, jak pytania retoryczne, wykrzykniki i wtrącenia, w połączeniu z określeniami typu: „ma się wrażenie”, „wydaje się”, kreuje atmosferę fragmentaryczności, subiektywizmu i braku kategorycznych rozstrzygnięć. 
Spoza wykorzystywanych przez Stracheya praktyk tekstowych wyziera obraz świata i sposób jego widzenia przez autora. Interpretacja wydarzeń odgrywa znaczenie prymarne $\mathrm{w}$ stosunku do faktu, co z kolei uwypukla zwątpienie w pełną możliwość poznania. Ani siła argumentacji, ani rzetelność metodologiczna nie liczą się w kreśleniu wizerunku bohaterki. Na plan pierwszy wysuwa się styl i ton wypowiedzi oraz błyskotliwość intelektualna autora. Wrażenie to zostaje wzmocnione poprzez posłużenie się paradoksem.

Paradoks uwidacznia się szczególnie w komentarzach dotyczących nie tyle życia opisywanych postaci, ile czasów, w których przyszło im żyć. Najwymowniejszym bodaj przykładem jest konkluzja biografii Gordona, która dotyczy "odbicia” Chartumu przez Anglików. Jako że umieszczona jest w czwartym eseju zbioru, jest także ostatnim zdaniem całej książki. Strachey zauważa: „W każdym razie wszystko skończyło się bardzo szczęśliwie - wspaniałą rzezią dwudziestu tysięcy Arabów, poważnym rozszerzeniem imperium brytyjskiego i tytułem lordowskim dla sir Evelyna Baring" [s. 270]. Podobnie paradoksalne stwierdzenie odnajdziemy też we fragmencie opisującym pracoholizm Florence Nightingale:

Czyżby laurowy wieniec zwycięstwa miał w ostatniej chwili wymknąć jej się z rąk? Ona nie da się odwieść od swojego zadania przez lekarzy; lekarze mówią głupstwa; niezbędną rzeczą jest nie odpoczynek, ale zreformowanie Ministerstwa Wojny; wie zresztą sama z własnego doświadczenia, ile można zrobić jeszcze wtedy, kiedy się jest już prawie umierającym [s. 86].

Strachey niszczy popularny mit, który przedstawiał Florence Nightingale jako „niebiańską bohaterkę marzeń" [s. 47], wyśmiewa obraz „Pani z latarnią" utrwalony także dzięki wierszowi "Santa Filomena” amerykańskiego poety Longfellowa, która „przesuwała się wśród okropności szpitala” [s. 13], opromieniając swoją dobrocią posłania umierających żołnierzy. Kieruje też ostrze krytyki przeciw społeczeństwu, kpiąc z wiktoriańskich stereotypów i roli kobiet oraz utartych oczekiwań w stosunku do dobrze urodzonych panien.

Byłoby rzeczą naturalną przypuszczać że Florence, wychowana w warunkach tak pociągających, okaże należyte zrozumienie dla ich wartości i spełni swój obowiązek wobec tej sfery życia, do której Panu Bogu podobało się ją powołać innymi słowy wyjdzie za mąż, po należytej liczbie przyjęć i zabaw tanecznych, za odpowiedniego gentlemana, i będzie z nim szczęśliwa do końca życia [s. 14].

Począwszy od tytułu, skończywszy na finalnym akapicie - ironia przepełnia całe dzieło Stracheya. Jest zarówno figurą retoryczną jak i postawą percepcyjną. Jest także taktyką dyskursywną w służbie odmitologizowania. 
Czworo wiktoriańskich "bohaterów” zostaje przedstawionych w sposób karykaturalny tylko dlatego, że uosabiają swą postawą wartości, którymi autor gardzi. Strachey był synem generała i dzieckiem wiktoriańskiej Anglii. Urodzony w 1880 roku miał dwadzieścia jeden lat, gdy zmarła królowa. Dorastał więc w czasach, gdy wartości epoki, z silnie akcentowaną ideologią ekspansji kolonialnej, przenikały każdy aspekt życia. Szczerze nie znosił tego typowego wówczas stosunku do rzeczywistości, który Walter E. Houghton określił mianem „wiktoriańskich ram myślenia" („the Victorian frame of mind") ${ }^{35}$, z ich czołobitnym kultem bohaterów, pochwałą siły, religijnym zapałem, wyższością moralną. Pacyfista i obdżektor, Strachey uniknął służby woskowej z powodu złego stanu zdrowia dopiero po procesie sądowym.

Początkowym zamiarem pisarza było przedstawienie dwunastu biografii $^{36}$. To, że postanowił zmniejszyć tę liczbę do czterech, wynikało z potrzeby reprezentatywności. Każda z wybranych postaci uosabia tę wartość wiktoriańską, którą zdecydował się ośmieszyć: nadętą bogobojność kardynała Manninga, fałszywy humanitaryzm Florence Nightingale, źle pojętą misję edukacyjną Thomasa Arnolda oraz imperialny zapał Generała Gordona. Wybujałe ambicje osobiste, pompatyczne przekonanie o własnej wielkości, pruderia i hipokryzja są nie tylko przywarami osobistymi, które obnaża, lecz w równej mierze cechami tamtych czasów. Wszyscy czworo stają się anty-bohaterami, obiektem drwin i ataku z pozycji nowej ery, gdyż to właśnie nowa epoka obwiniała starą, wierząc, że wiktoriańska mentalność odegrała niemałą rolę w doprowadzeniu do Wielkiej Wojny, a co za tym idzie, ponosi odpowiedzialność za tragedię narodu. Ironia i kpina, śmiech i szyderstwo stają się dla Stracheya narzędziem walki w służbie modernistycznego anty-wiktorianizmu.

Ludzie epoki Wiktorii to pierwsza, lecz nie jedyna propozycja biograficzna Stracheya. W latach 1921-1931 powstały jeszcze Królowa Wiktoria (Queen Victoria, 1921) oraz Elżbieta i Essex. Historia Tragiczna (Elizabeth and Essex. A Tragic History, 1928), ale to właśnie Ludzie epoki Wiktorii przynieśli Stracheyowi rozgłos. Uważa się, że dzięki tej publikacji gatunek biografii został zmieniony na zawsze ${ }^{37}$. Porzucono rozpowszechnione wcześniej zabiegi gloryfikujące bohatera i większą wagę przypisano umiejętnościom krytycznym i wartości

35 W. Houghton, The Victorian Frame of Mind, 1830-1870, New Haven and London 1985.

36 R. Tekcan, The Biographer and the Subject: A Study of Biographical Distance, Stuttgart 2014, s. 70 .

37 Zob. B. Hooper, Another Look At: Lytton Strachey's Eminent Victorians, „Booklist” 15.06.2011, s. 28; B. de Haan i H. Renders, Towards Traditions and Nations, w: Theoretical Discussions of Biography: Approaches from History, Microhistory and Life Writing, ed. B. de Haan i H. Renders, Leiden 2014, s. 11-23. 
literackiej. Jeśli traktujemy publikację Eminent Victorians jako moment przełomowy $\mathrm{w}$ pisarstwie biograficznym, to jest tak dlatego, że $\mathrm{w}$ rozumieniu biografa, i konsekwentnie w przyjętej postawie, walory literackie tekstu po raz pierwszy uzyskują prymat nad poprawnością faktograficzną. Celem staje się dobrze opowiedziana, zajmująca historia. Biograf puszcza wodze fantazji, umieszcza fikcyjne cytaty, przemilcza niektóre fakty, inne stwarza, nie zadaje sobie trudu, aby zweryfikować informację. Wprost przeciwnie, dla pożądanego efektu manipuluje prawdą. Richard Altick krytykując po-Stracheyowską szkołę biografii, według której źródła należy traktować wybiórczo, przytacza informację, że André Maurois komponując biografię wielkiego romantyka angielskiego P.B. Shelleya, ani razu nie wspomniał, że ten był poetą - ważniejsze okazały się subiektywne impresje, kunszt języka, błyskotliwy dowcip ${ }^{38}$. Dla Stracheya, z wykształcenia historyka, mijanie się z prawdą i niechęć do rzetelnego poszukiwania źródeł są konsekwencją przekonania, że nie ma jednej wizji świata i jednej wizji życia. Ignorowanie wiedzy osób, które znały bohaterów, wybiórcze traktowanie źródeł, brak obiektywizmu, wymyślanie niemających miejsca dialogów, tworzenie zabawnych monologów wewnętrznych, wydają się uprawnione, gdyż służą celowi nadrzędnemu. Biograf nowego typu staje się enfant terrible w swoim pragnieniu zniszczenia posągowości, odbrązowienia ideału, wyśmiania wszystkiego, co znienawidzone, a jego dzieło to autonomiczna kreacja artystyczna. Jednocześnie jednak poprzez swoje obrazoburstwo, szkice Stracheya zyskują wyraźny wymiar społeczny, stając się krytyką w imię walki z głupotą.

W Ludziach epoki Wiktorii znajdziemy liczne przykłady jawnej nieprawdy i ukazywania bohaterów w fałszywym świetle. Data urodzin Kardynała Manninga jest błędna (to rok 1807, zamiast 1808). Doktor Arnold opisany zostaje jako mężczyzna o nieproporcjonalnie krótkich nogach, czemu przeczą źródła historyczne. Jednocześnie jednak, jak zgodnie twierdzą historycy biografii jako gatunku ${ }^{39}$, Strachey jako pierwszy wyposażył biografię $w$ techniki narracyjne wcześniej wykorzystywane jedynie w fikcji literackiej, zwłaszcza powieściopisarstwie: flashback, zaburzoną nielinearną chronologię, monolog wewnętrzny, dystans ironiczny. Zamiast próby rekonstrukcji wydarzeń zaproponował interpretację i szerszy kontekst. Życie jednostek posłużyło mu do ukazania epoki i wywołania dyskusji. Co do roli utworu Stracheya w „zreformowaniu gatunku" panuje powszechna zgodność. Po nim, nikt już nie pi-

38 R. D. Altick, Eminent Victorianism. What Lytton Strachey Hath Wrought, „The American Scholar" 1995, 64:1, s. 86.

39 Zob. N. Hamilton, Biography. A Brief History, Cambridge, Ma. and London 2007. 
sał tak, jak pisano przed nim. Według Floriane Reviron-Piégay ${ }^{40}$, podejście Stracheya radykalnie i na zawsze zmieniło związek między biografem i obiektem biografii, faktem i fikcją, biografią i historią. Należy zatem uznać Eminent Victorians za pozycję epokowo ważną, która ugruntowała w tradycji anglosaskiej przekonanie, że biografia jest tekstem literackim, a nie narodowo-historycznym pomnikiem wystawionym przez potomnych.

Strachey należał do pokolenia modernistów. Zaprzyjaźniony z Virginią Woolf i E. M. Forsterem był przedstawicielem londyńskiej bohemy. Piętno nowych czasów widoczne jest w Eminent Victorians w wielu aspektach. Kryzys wartości, atak na obskurantyzm, mentalność i moralność mieszczańską, duch protestu i rebelii, postawa oskarżycielska, przekonanie o roli artysty i wiara w potęgę pisarstwa impresyjnego na wskroś przepełniają narrację. Budując portrety psychologiczne, Strachey posługuje się często insynuacją. Nigdzie nie twierdzi wprost, że Gordon był homoseksualistą a Nightingale tłumiła potrzeby seksualne, lecz można to wyczytać między wierszami. W utworze widoczny jest zatem wyraźny wpływ Freuda i jego publikacji na temat podświadomości. Czytelna jest również sugestia (na owe czasy nowatorska), że doświadczenia seksualne, bądź ich brak, kształtują podświadomość. Położony $\mathrm{w}$ przedmowie autorskiej nacisk na rolę biografa w odszyfrowaniu motywów postępowania bohatera, a także na konieczność podejmowania prób interpretacji zachowań można umieścić w kontekście modernistycznego zainteresowania psychologią postaci. James Walter ${ }^{41}$ tłumaczy brak obiektywizmu Eminent Victorians modernistyczną potrzebą przyjęcia określonego punktu widzenia. Skoro poznanie prawdy nie jest możliwe, a to, co ukryte lub nieuświadomione ma siłę sprawczą, może za bardziej celowe należy uznać chwytanie wrażeń i taką selekcję materiału, która udowodni przyjęte założenie. Dzieło Stracheya wyraźnie wykazuje wpływ epoki, ujawniając wiele cech utożsamianych z modernizmem i twórczością artystów kręgu Bloomsbury, egzemplifikując „nowe rozumienie rzeczywistości, oparte na subiektywizmie, relatywizmie i fragmentaryczności postrzegania" 42 .

40 F. Reviron-Piégay, The Age of Outrage: Eminent Victorians: Outrageous Strachey? The Indecent Exposure of Victorian Characters and Mores, "Études britanniques contemporaines" 2017, https://ebc.revues.org/638 [dostęp 10.01.2017].

41 J. Walter, The Solace of Doubt? Biographical Methodology after the Short Twentieth Century, w: Theoretical Discussions of Biography: Approaches from History, Microhistory and Life Writing, ed. B. de Haan i H. Renders, s. 43.

42 K. Stamirowska, Bloomsbury i Virginia Woolf, w: Grupa Bloomsbury. Brytyjska bohema kregu Virginii Woolf, Kraków 2010, s. 28. 
W kwestii dogłębnego zrozumienia przedstawionych bohaterów i ich czasów opinie współczesnych są podzielone. Niektórzy badacze uważają, że książka Stracheya odegrała znaczącą rolę w podejściu do wiktorianizmu i ukazaniu zawiłych uwarunkowań psychologicznych kształtujących epokę, inni twierdzą, że przyczyniła się do utrwalenia krzywdzącego stereotypu ${ }^{43}$. Bezsprzecznie odniosła sukces, stając się synonimem postawy antywiktoriańskiej. Houghton uważa, że sami Wiktorianie, którzy ze szczerym przekonaniem i oddaniem broniliby zapewne własnej pozycji przeciwko krytyce różnych, jak to ujmuje, „Lyttonów Stracheyów XX wieku” ${ }^{44}$, bezwarunkowo opowiadając się za dogmatyzmem, siłą i sztywnym gorsetem zasad moralnych, przyznaliby się co do jednego - hipokryzji. Udawali lepszych, niż byli $\mathrm{w}$ istocie, woleli odwracać wzrok niż stawić czoła prawdzie ${ }^{45}$.

Ludzie epoki Wiktorii Lyttona Stracheya to utwór, w którym ironię odczytać można jako akt komunikacyjny adresowany do czytelnika świadomego przemian społecznych w czasach powiktoriańskich. W tym rozumieniu, rozpoznanie ironicznego wymiaru utworu uwarunkowane jest istnieniem grona odbiorców zdolnych do identyfikacji licznych powiązań pozaliterackich i pozatekstowych. Co za tym idzie, zależy od istnienia tzw. „wspólnoty dyskursywnej". Autor posługuje się ironią w celu odbrązowienia zmitologizowanych postaci życia publicznego dziewiętnastowiecznej Anglii, jednocześnie wpisując się w modernistyczne rozumienie świata. Szkice biograficzne Stracheya mogą stanowić egzemplifikację twierdzenia Alana Wilde'a, że ironię należy rozpatrywać $\mathrm{w}$ ujęciu historycznym i że za charakterystyczne cechy ironii modernistycznej trzeba uznać zarówno postawę ironisty opartą na artykułowaniu i konfrontowaniu fragmentaryczności („disjunctive irony”), jak i posługiwanie się dyskursem wykorzystującym paradoks dla osiągnięcia efektu artystycznego. Eminent Victorians to książka, która zrewolucjonizowała podejście do biografistyki. Kwestionując istnienie jedynej prawdy, kontestując autorytety i pochwałę wielkości, Strachey zapoczątkował jednocześnie nową tradycję biografii literackiej na gruncie anglosaskim. Ironię utworu, widoczną zarówno na poziomie pojedynczych zabiegów stylistycznych, jak i w ogarniającej cały tekst postawie biografa, ukształtowała intelektualna atmosfera modernizmu panująca wokół artystów grupy Bloomsbury z ich radykalnym odrzuceniem hipokryzji i ideologii imperialnej, a także szerzej, wśród tych przedstawicieli społeczeństwa, którzy za koszmar pierwszej wojny światowej winili ekspansywną politykę prowadzoną przez Wielką Brytanię. Nowy

\footnotetext{
43 R. Tekcan, The Biographer and the Subject: A Study of Biographical Distance, s. 147.

44 W. Houghton, The Victorian Frame of Mind, 1830-1870, s. 384.

45 Tamże, s. 395.
} 
typ biografii zaproponowany przez Stracheya w sposób bezpośredni wynika z modernistycznego pojmowania rzeczywistości, w którym dominuje odczucie subiektywne i fragmentaryczność postrzegania i w którym zerwanie więzów wiktoriańskiej etykiety stanowi akt wyzwolenia i prowadzi do rozwoju artystycznego i intelektualnego. Ironia Ludzi epoki Wiktorii jest jednocześnie rodzajem dyskursu, postawą opartą na rozumieniu świata i podejściu do rzeczywistości oraz aktem komunikacyjnym o wymiarze społecznej krytyki.

Rozpatrując ironię z antropologicznego punktu widzenia, Zofia Mitosek pisze:

Ironia jest postawą dystansu wobec rzeczywistości, rozpoznaniem w niej splotu nieuchwytnych sprzeczności, skłóconych dążeń i konfliktowych racji. Stanowi ekspresję podmiotu, który mając określony system wartości, kwestionuje to, co uznaje za jego odwrócenie. Odczuwając pogardę wobec odmiennych norm i zachowań, ironista piętnuje je i wyśmiewa, nadając wypowiedzi sens przeciwny w stosunku do wyrażanego wprost lub przedstawiając sytuację sprzeczną z sytuacją pożądaną. Postawa autora nie musi się ujawniać poprzez ironiczne zwroty. Wysoki styl ironiczny charakteryzuje się tym, że zrzeka się gromadzenia poszczególnych uwag na korzyść ironii głębszej, artykułowanej w fabule i narracji ${ }^{46}$.

Uwagi te znajdują wymowne i jednoznaczne potwierdzenie w omówionym powyżej utworze Lyttona Starcheya Ludzie epoki Wiktorii.

\section{Bibliografia}

Allemann Beda, O ironii jako o kategorii literackiej, przeł. M. Dramińska-Joczowa, w: Ironia, red. M. Głowiński, Gdańsk: Słowo/obraz terytoria, 2002, s. 17-41.

Adamczyk-Garbowska Monika, Polskie tłumaczenia angielskiej literatury dziecięcej. Problemy krytyki przekładu, Wrocław: Zakład Narodowy im. Ossolinnskich, Wydawnictwo PAN, 1988.

Altick Richard D., Eminent Victorianism. What Lytton Strachey Hath Wrought, „The American Scholar" 1995, vol. 64, no 1 (Winter), s. 81-89.

Barbe Katherina, Irony in Context, Amsterdam/Philadelphia: John Benjamins, 1995.

Bové Paul A., Modern Irony and the Ironic Imagination, "Contemporary Literature" 1982, vol. 23, issue 2 (Spring), s. 244-254.

Dane Joseph A., The Critical Mythology of Irony, Athens and London: U. of Georgia Press, 2011.

Głowiński Michał, Ironia jako akt komunikacyjny, w: Ironia, red. M. Głowiński, Gdańsk: Słowo/obraz terytoria, 2002, s. 5-16.

46 Z. Mitosek, Co z tą ironia?, s. 355. 
Hamilton Nigel, Biography. A Brief History. Cambridge, Ma. and London: Harvard UP, 2007.

Haan de Binne, Renders Hans, Towards Traditions and Nations, w: Theoretical Discussions of Biography: Approaches from History, Microhistory and Life Writing, eds. B. de Haan, Binnee, H. Renders, Leiden: Brill, 2014, s. 11-23.

Hooper Brad, Another Look At: Lytton Strachey's „Eminent Victorians”, „Booklist” 2011, vol. 107, issue 19/20, s. 28.

Houghton Walter, The Victorian Frame of Mind, 1830-1870, New Haven and London: Yale University Press, 1985.

Hutcheon Linda, Irony's Edge: The Theory and Politics of Irony, London and New York: Routledge, 1995.

Hutcheon Linda, „Ironia, satyra, parodia - o ironii w ujęciu pragmatycznym”, przeł. K. Górska, w: Ironia, red. M. Głowiński, Gdańsk: Słowo/obraz terytoria, 2002, s. $165-190$.

Kerbrat-Orecchiani Catherine, Ironia jako trop, przeł. M. Dramińska-Joczowa, w: Ironia, red. M. Głowiński, Gdańsk: Słowo/obraz terytoria, 2002, s. 109-143.

Korwin-Piotrowska Dorota, Poetyka: przewodnik po świecie tekstów, Kraków: Wydawnictwo Uniwersytetu Jagiellońskiego, 2011.

Łaguna Piotr, Ironia jako postawa i jako wyraz, Kraków-Wrocław: Wydawnictwo Literackie, 1984.

May Brian, The Modernist as Pragmatist: E. M. Forster and the Fate of Liberalism, Columbia and London: Univ. of Missouri Press, 1997.

McCrum Robert, „Eminent Victorians”, „Guardian”, 16 stycznia 2017.

Melbye David, Irony in the Twilight Zone: How the Series Critiqued Postwar American Culture, Lanham: Rowman and Littlefield, 2016.

Miller Tyrus, Late Modernism: Politics, Fiction, and the Arts between the World Wars, Berkeley-Los Angeles-London: U. of California Press, 1999.

Mitosek Zofia, Co z ta ironia?, Gdańsk: Słowo/obraz terytoria, 2013.

Muecke D. S., Ironia: podstawowe klasyfikacje, przeł. G. Cendrowska, w: Ironia, red. M. Głowiński, Gdańsk: Słowo/obraz terytoria, 2002, s. 43-74.

Paxman Jeremy, Empire, London: Penguin Books, 2011.

Reviron-Piégay Floriane, The Age of Outrage: Eminent Victorians: Outrageous Strachey? The Indecent Exposure of Victorian Characters and Mores, „Études britanniques contemporaines" 2013, nr 45, https://ebc.revues.org/638, DOI: 10.4000/ebc.638.

Rodriguez Rosique Susana, The power of inversion. Irony, from utterance to discourse, w: Irony and Humour. From Pragmatics to Discourse, eds. L.R. Gurillo, M. Belén Alvaro Ortega, Amsterdam/Philadelphia: John Benjamins, 2013, s. 17-38.

Skidelsky Robert, Only Connect: Biography and Truth, w: The Troubled Face of Biography, ed. E. Homberger, J. Charmley, New York: Macmillan, 1988, s. 1-16.

Sperber Dan, Deirdre Wilson, Ironia a rozróżnienie między użyciem a przywołaniem, przeł. M. B. Fedewicz, w: Ironia, red. M. Głowiński, Gdańsk: Słowo/obraz terytoria, 2002, s. 75-108.

Stamirowska Krystyna, Bloomsbury i Virginia Woolf, w: Grupa Bloomsbury. Brytyjska bohema kręgu Virginii Woolf, Kraków: Międzynarodowe Centrum Kultury, 2010, s. $23-31$. 
Storrm William, Irony and the Modern Theatre, Cambridge: CUP, 2011.

Strachey Lytton, Eminent Victorians, New York: Garden City, 1918.

Strachey Lytton, Ludzie epoki Wiktorii. Florence Nightingale. Generał Gordon, przeł. A. Pański, Warszawa: Towarzystwo Wydawnicze „Rój”, 1938.

Tekcan Rana, The Biographer and the Subject: A Study of Biographical Distance, Stuttgart: ibidem-Verlag/ibidem Press, 2014.

Walczuk Anna, Irony as a Mode of Perception and Principle of Ordering Reality in the Novels of Muriel Spark, Kraków: Universitas, 2005.

Walter James, The Solace of Doubt? Biographical Methodology after the Short Twentieth Century, w: Theoretical Discussions of Biography: Approaches from History, Microhistory and Life Writing, eds. B. de Haan, Binnee, H. Renders, Leiden: Brill, 2014, s. $43-58$.

Wilde Alan, Modernism and the Aesthetic of Crisis, "Contemporary Literature" 1979, vol. 20, issue 1, s. 13-50.

Wilde Alan, Horizons of Assent: Modernism, Postmodernism, and the Ironic Imagination, Baltimore: Johns Hopkins U. Press, 1987.

\section{Modernist Irony and a New Type of Biography: Eminent Victorians by Lytton Strachey}

\section{Summary}

The article argues that Lytton Strachey's Eminent Victorians (1918) exemplifies the use of modernist irony, as defined by Alan Wilde in Horizons of Assent: Modernism, Postmodernism, and the Ironic Imagination (1981). The Polish translation of Strachey's book, which includes only two of the four original essays, while losing the ironic undertones of the title in Ludzie epoki Wiktorii, keeps some significant characteristics discussed by Wilde, such as disjunction, paradox and parataxis. Strachey's disjunctive irony, his awareness of life's incongruities and disparities, his perspective of distance and detachment, as well as his employment of narrative techniques suggesting discontinuity, fleeting impression and subjectivity - all lie at the root of the new form of biography as a genre.

Keywords: modernist irony, disjunctive irony, biography, Eminent Victorians, Lytton Strachey, modernism, Alan Wilde 